\title{
Characteristic Qualities Affecting Landed House Prices
}

\author{
Muhamad Hilmi Mohamad @ Masri ${ }^{1 *}$, Abdul Hadi Nawawi', \\ Edie Ezwan Mohd Safian², Ahmad Fawwaz Ahmad Saleh
}

\author{
${ }^{1}$ Faculty of Architecture, Planning and Surveying, \\ Universiti Teknologi MARA, Malaysia \\ ${ }^{2}$ Faculty of Technology Management and Business, \\ Universiti Tun Hussein Onn Malaysia \\ *hilmimasri@gmail.com
}

\begin{abstract}
The research was conducted to find the characteristics quality of houses in Malaysia. The aim of this research was to produce the ranking characteristics of house qualities and determining its weightages. The methodology used in this research was primarily by using the Delphi Method to ascertain characteristics quality and also Analytical Hierarchy Process to determine the ranking of the characteristics quality. Data collection gathered through a structured questionnaire that incorporates the element of Saaty's Scale using variables outlined from review and interview. A theoretical framework of the research was established from this that will lead to future research model.
\end{abstract}

Keywords: House Quality; House Price; AHP; Delphi

eISSN 2398-4279 @ 2018. The Authors. Published for AMER ABRA cE-Bs by e-International Publishing House, Ltd., UK. This is an open access article under the CC BY-NC-ND license (http://creativecommons.org/licenses/bync-nd/4.0/). Peer-review under responsibility of AMER (Association of Malaysian Environment-Behaviour Researchers), ABRA (Association of Behavioural Researchers on Asians) and cE-Bs (Centre for EnvironmentBehaviour Studies), Faculty of Architecture, Planning \& Surveying, Universiti Teknologi MARA, Malaysia.

DOI: https://doi.org/10.21834/ajqol.v3i12.137 


\subsection{Introduction}

The characteristics quality of houses are significant to find out especially in Malaysia, and how this can affect their prices and concurrently the livelihood of home buyers. The researcher provides the aim of this research as to produce ranking characteristics of housing qualities. Objectives outlined were mainly to find out characteristics quality of houses, and ranking the importance of the characteristics quality.

The Analytical Hierarchy Process was used as the methodology of the research to extract and determine a ranking of characteristics quality. The usage of a structured questionnaire consisting elements of Saaty's Scale was used to gather data for the research. The main findings of the research have shown that characteristics being described and paired up together had an importance that was significant in a way that affects the quality of life of the respondents. The usage of Saaty's Scale and the AHP was implemented to provide uniqueness of the rankings produced by this research.

\subsection{Literature Review}

\subsection{Characteristics of Housing in Local and Global Context}

Karim (2012) states that housing should not be limited to a particular set of house characteristics, but it must be a whole presentation of physicality and also social aspects. Omar, Omar, Othman, \& Yusoff,(2016) also state that concern must not only be on the physical part, but other features such as location and neighbourhood should be addressed.

In summary, the majority of countries in the world have some form of standard and guidelines for characteristics quality of houses being provided. The argument is that whether these qualities were being provided sufficiently or not, and what are the ways to measure and give weightings to them.

\subsection{Designation and Identification of Building, Locational and Neighbourhood Characteristics of Housing}

The research done by all the researchers outlined are usually tested and can be used as additional characteristics in research especially (Safian, Nawawi, \& Sipan, 2014). Outlined in the table below are the characteristics derived from literature review and to achieve the first objective of research which was to find out characteristics qualities of houses.

Table 1.1 Characteristics of Houses Outlined

\begin{tabular}{ll}
\hline Main Characteristics & Sub-Characteristics \\
\hline Functionality & Layout Plan \\
& Materials Durability \\
& Number of Rooms \\
& Building Structure \\
Presentation & Electrical System \\
& Number of Storeys \\
& Finishing Appearance \\
& Flooring Material \\
& Building Built Area \\
& Building Age \\
\hline
\end{tabular}




\begin{tabular}{|c|c|}
\hline & Landscaping Works \\
\hline \multirow[t]{6}{*}{ Environment } & Drainage \\
\hline & Open Spaces \\
\hline & Green Spaces \\
\hline & External Specification \\
\hline & Playing Facilities \\
\hline & Facilities for Interaction \\
\hline \multirow[t]{6}{*}{ Amenities } & Gated Housing Area \\
\hline & Parking Provisions \\
\hline & Lighting \\
\hline & Social Practices \\
\hline & Conducted \\
\hline & Neighbour \\
\hline \multirow[t]{8}{*}{ Community } & Communications \\
\hline & Fire Safety \\
\hline & Housing Developments \\
\hline & New/old Township \\
\hline & Security \\
\hline & Cleanliness \\
\hline & Noise Level \\
\hline & Rubbish Collection \\
\hline \multirow[t]{5}{*}{ Management } & Maintenance \\
\hline & Provision of Public \\
\hline & Transport \\
\hline & Nearby Housing \\
\hline & Developments \\
\hline \multirow[t]{9}{*}{ Location } & Nearby Central \\
\hline & Business Districts \\
\hline & Distance to City Centre \\
\hline & Traffic Congestion \\
\hline & Nearby Highways \\
\hline & Road Networks \\
\hline & Fibre Internet Services \\
\hline & Driveway \\
\hline & Ingress/egress from \\
\hline Access & Residential Area \\
\hline
\end{tabular}

Table 1.1 shows the overall characteristics and sub-characteristics of housing that has been studied from local and global context perspective and will be used as the variables in this research.

\subsubsection{The Compilation Framework of Housing Characteristics Qualities}

From the literature review analysis, the framework of the housing characteristics was outlined as above. By addressing the characteristics through measuring and ranking the characteristics, issues of complexity and high prices can be resolved, as shown in Figure 1.

\subsection{Measurement of Characteristics of Housing}

Several studies conducted by Basten \& Koch, (2015), and Rahadi, Wiryono, Koesrindartoto, \& Syamwil, (2013) showed that measurement towards quality are mostly conducted through the qualitative approach and was finely tailored to fit industry regulations. This statement showed that they are areas overlooked and not addressed properly particularly on methods to measure the quality level of housing.

Panduro \& Veie, (2013) agrees that qualitative approach can be too descriptive and their 
interpretations were loose in determining characteristics quality of houses and its weight. Masri, Nawawi, \& Sipan (2016) states that in Malaysia, identifying characteristics qualities of houses using descriptive measurements are not sufficient and rigorous enough. Saleh, Hwa, \& Majid, (2016) supports this idea by saying the quality of houses are not determined by their physical characteristics but also influenced by unseen factors surrounding the houses.

Based on the previous discussion, it is vital that this research can characteristics, based on each quality level characteristics qualities of houses. To gain rigorous insight towards this, several methods were needed to be identified and analysed to choose the best method that has the capability of overcoming the stated issues and problems in earlier discussions. The stated matter will then be discussed in detail in the upcoming sub-topic.

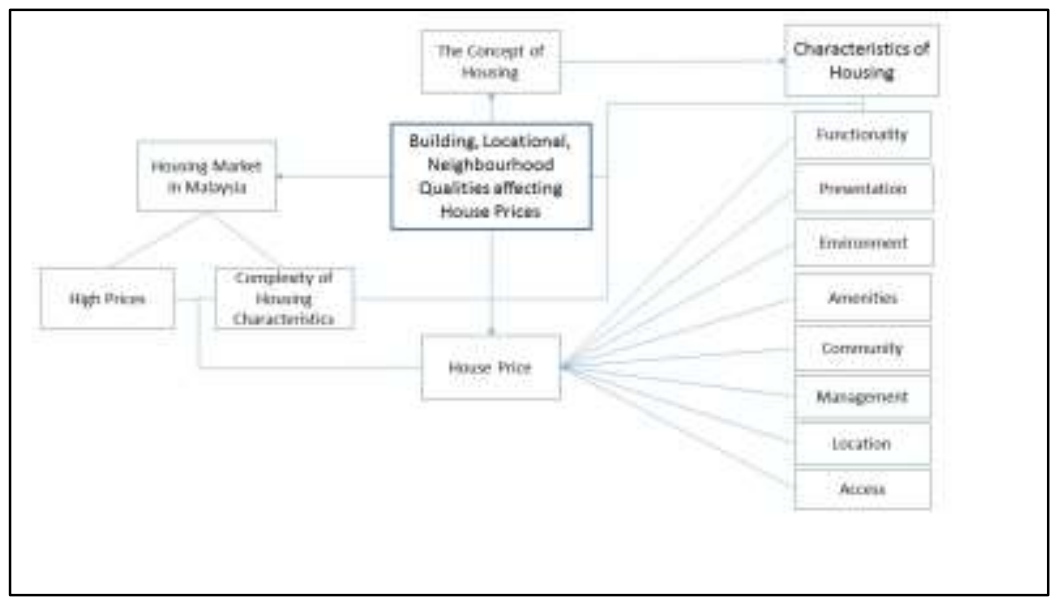

Figure 1: Framework of Housing Characteristics

\subsection{Methodology}

\subsection{Qualitative Method}

\subsubsection{Delphi Method}

Delphi method is a research methodology whereby a particular group of people a joined up together for communication process to happen and to establish solution towards overcoming

The expert panels being interviewed using Delphi Method are covered in several rounds, mainly two times by the researcher. Delphi Method can gather information and consensus without revealing the identity of expert panels between one another (Quyên, 2014). The two rounds of interview aim to give a review to the opinions and contributions given by all the panels, and the result is expected that all the panels will agree with the set of indicators achieved (Radeljak Kaufmann, 2016).

Based on the method discussed earlier, the researcher was needed to consider this 
particular method that can be reliable and suitable to determine the ranking of house characteristics. The procedure for this can be shown in Table 2 which states to the process of how the Delphi Method was implemented in the research.

\subsection{Quantitative Method}

\subsubsection{Questionnaire Survey}

To achieve the second objective of the research which is to rank the importance of characteristics quality of houses, a quantitative method has to be implied. The researcher, therefore, has adopted the Analytic Hierarchy Process to rank the weightage and importance of the house characteristics. The AHP method is systematic measurement method adopted for selecting, ranking and also justifying elements of research, and have the hierarchical structure analysis concept (Abdullah, Jaafar, \& Taib, 2013).

The AHP gives a ranking of importance thus can answer important questions particularly on the house characteristics (Dinarvandi, Jafari, Mohamadi, \& Hosseini, 2014). The usage of qualitative and quantitative method together will then help structure problems into systematic hierarchy, and the usage of quantitative through questionnaire survey will become the check and balance that determine validity of characteristics based on the opinions of respondents

From the previous discussion conducted, the AHP Method is not without its limitations. Previous studies conducted by Safian \& Nawawi, (2013), Dinarvandi et al., (2014), showed that owners, tenants, and occupants are prospective respondents for the questionnaire survey incorporating AHP. Similar researches conducted by Mulliner, Smallbone, \& Maliene, (2013) and Khoiry et al., (2012) have also shown that the occupants and owners of houses can become the best respondents due to their knowledge and experience living, in particular, residential areas.

Table 2: Research Method and Sampling

\begin{tabular}{|c|c|c|c|}
\hline $\begin{array}{l}\text { Stage of } \\
\text { Research }\end{array}$ & Research Objective & Research Methods \& Types of Data & Selection of Sample \\
\hline Stage 1 & $\begin{array}{l}\text { 1.Identify characteristics } \\
\text { quality of houses }\end{array}$ & $\begin{array}{l}\text { Qualitative data } \\
\text { Research Instrument: } \\
\text { - Preliminary Framework } \\
\text { (Literature Review, Source } \\
\text { Documents) } \\
\text { Method: } \\
\text { - Semi-structured Interviews: } \\
\quad \text { Delphi Method } \\
\text { Respondents: } \\
\text { - Four Expert Panels }\end{array}$ & $\begin{array}{cll}\text { Interview conducted by four } \\
\text { expert panels comprising of: } \\
\text { 1. Two Valuers } \\
\text { 2. One developer } \\
\text { 3. } & \text { One } & \text { Estate } \\
& \text { Agent } & \end{array}$ \\
\hline Stage 2 & $\begin{array}{l}\text { 2. To rank importance of } \\
\text { house characteristics } \\
\text { quality }\end{array}$ & $\begin{array}{l}\text { Quantitative Data } \\
\text { Weightage of Importance: } \\
\text { Instrument: } \\
\text { - Questionnaire Surve } \\
\text { Method: } \\
\text { - Analytical Hierarchy Process } \\
\quad \text { (AHP) }\end{array}$ & $\begin{array}{clc}\text { Sampling of Houses } & \\
\text { 1. } & \text { Bandar } & \text { Bukit } \\
& \text { Raja } & \\
\text { 2. } & \text { Taman Klang } \\
\text { 3tama } & \\
\text { 3. } & \text { Aman Perdana } \\
\text { 4. } & \text { Bandar } & \text { Bukit } \\
& \text { Tinggi } & \end{array}$ \\
\hline
\end{tabular}


Respondents:

5. Bandar Botanic

- $\quad$ One respondent per household

Sample:

Simple Random Sampling

- Ten household per residential area

- Total 50 households involved

\subsection{Findings}

\subsection{Delphi Method Findings}

In the first stage of the Delphi Method Interview, the researcher has prepared the draft characteristics quality of houses that were derived from the literature review. Each of the chosen expert panels was given the same draft characteristics quality of houses that they can read and give comments and opinions. The Delphi Method being used in this research was a 2 stage system, which the first stage was to ascertain the characteristics quality of houses by the expert panels, and the second stage is the researcher makes amendments based on the comments and discussions. The second draft of characteristics quality of houses was then compiled and brought to the expert panels for validation. The findings highlighted will then be further discussed in the next sub-topic.

\section{Table 3: Delphi Method Findings}

\begin{tabular}{|c|c|c|}
\hline Matter & Objective of Researcher & Highlighted Findings \\
\hline Round 1 Delphi Interview & $\begin{array}{l}\text { In the first round, the } \\
\text { researcher has to obtain the } \\
\text { opinions, views and critiques } \\
\text { from the expert panels in } \\
\text { particular with the drafted } \\
\text { characteristics quality of } \\
\text { houses. The results will then } \\
\text { be used to improve the draft } \\
\text { and brought forward to be } \\
\text { validated in the second } \\
\text { round of interview. }\end{array}$ & $\begin{array}{l}\text { 1. The majority of expert panels } \\
\text { interviewed agree with the } \\
\text { prescribe characteristics } \\
\text { quality of houses outlined by } \\
\text { the researcher. One expert } \\
\text { panels give a critique that the } \\
\text { characteristics should be } \\
\text { enhanced further with more } \\
\text { detailed sub-characteristics. } \\
\text { The concept of using the } \\
\text { characteristics as ranking to } \\
\text { find out weightage of } \\
\text { importance was unanimously } \\
\text { agreed amongst the expert } \\
\text { panels. }\end{array}$ \\
\hline Round 2 Delphi Interview & $\begin{array}{l}\text { In the second round, the } \\
\text { researcher has compiled all } \\
\text { of the comments and } \\
\text { opinions from expert panels } \\
\text { into an amended draft of } \\
\text { characteristics. The } \\
\text { researcher needs the } \\
\text { validation from the experts } \\
\text { to proceed with } \\
\text { questionnaire survey to }\end{array}$ & $\begin{array}{l}\text { 1. In the second round, the } \\
\text { upgraded draft characteristics } \\
\text { were given back to expert } \\
\text { panels for them to re-asses } \\
\text { any changes that are needed } \\
\text { to be made. Unanimously the } \\
\text { expert panels agree with the } \\
\text { characteristics provided. } \\
\text { The draft questionnaire that } \\
\text { was made based on }\end{array}$ \\
\hline
\end{tabular}


respondents and determine

a rank of importance. characteristics were also

shown for views and

feedbacks.

\subsection{AHP Findings}

The AHP analysis was conducted by gathering all the respondent's perception based on the questionnaire survey distributed to them earlier. The researcher has utilised the AHP template provided by (Goepel, 2010) that has facilitate ease into the ranking of importance characteristics quality of houses. This, in turn, has provided the ranking based on some criteria from 1 until 8 . Number one will be the most important and the number eight to be least important.

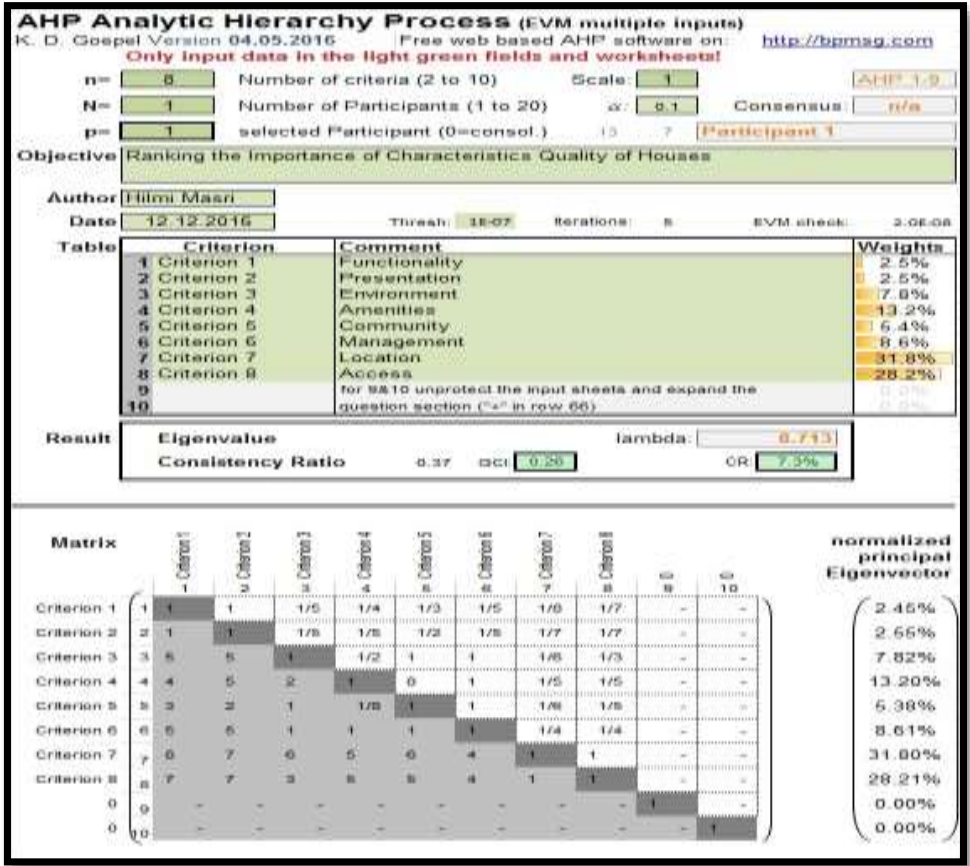

Figure 3: Findings through AHP Analysis to Rank Importance Characteristics Quality of Houses

\subsection{DISCUSSION}

\subsection{Healthy food behaviour}

This study shows a $100 \%$ increase in healthy food behaviour during the post-test. This finding indicates that there is an increase in healthy food behaviour in the post-intervention 
programme compared to pre-intervention but it also showed that overweight and obese school children who have knowledge and healthy food behaviour still need practice them in their daily lives after the intervention programme. This finding also demonstrates that overweight and obese school children have knowledge in choosing the 'best' or right food behaviour in their dietary patterns. This may be influenced by their parents, peers, and environment. In addition, the usage of educational media such as comics and videos in this NEP may be capable to attract overweight and obese school children to give more attention in learning and understanding the food pyramid and a balanced diet. Games on selecting healthy food enable the children to develop decision making skills in selecting healthy food without being influenced by parents, and peers. This finding is supported by a previous study by Başkale \& Bahar, (2011) which found that nutrition educations increased score nutrition knowledge and nutrition behaviour where the experimental group between pre-test and posttest 1 was significant; and pre-test and post-test 2 was also significant $(p-<.001)$. Demirozu, Pehlivan, \& Camliguney (2012) suggested that in order to influence the knowledge and healthy food behaviour of obese school children, nutrition education must be done through multiple channels such as in the school, parents and media..

\subsection{Attitude towards fruits and vegetables}

The results indicate that the overweight and obese school children had a significant increase in positive attitude towards fruits during the post-test, hence decreasing the attitudes that need to be observed. The attitude on vegetables' consumption has also shown a significant increase in post-intervention. Ranges that need to be observed decreased after the intervention programme. Overall, these results indicate that the NEP conducted in this study helped to enhance the attitude towards consumption of fruit and vegetables by overweight and obese school children. This result agrees with findings by Preplip et. al (2011) which showed significant changes in teacher influence on attitude towards consumption of fruits and vegetables for pre- and post-test in the intervention school. A previous study on nutrition education has shown the nutritious attitude score among the intervention group of children in rural areas to be higher as compared to urban areas (Ruzita At, Wan Azdie MAB,2007).

\subsection{Environment selection of fruits and vegetables}

The results indicate that NEP has only a minimal impact in relation to healthy environment between pre- and post-intervention. . These may be due to environmental factors of overweight and obese school children such as parents, peers, home environment, hawkers, media, economic factor and school canteen which influence the environment selection of food especially fruits and vegetables.

Binkiewicz-Glińska et al. (2012) found that school children were more likely to buy rice, sweet biscuits, and junk food compared to buying fruits and vegetables. Marketing strategies were also in place to maximise sales of unhealthy products. Furthermore, the factor of television food advertisements may influence food consumption among school children. These media may contribute to the development of child and adolescent obesity where screen time advertising of junk food and fast food increases children's requests for those particular foods and products (Strasburger, 2011). 
Maternal influence was also a predicator environmental influence on dietary pattern of fruits consumption and vegetables consumption among school children. This may be due to mothers having a greater degree of control over their child's food intake and influence their daughters' weight and eating habits, hence placing daughters at risk for developing problematic eating behaviours (Scaglioni et al., 2008). The mothers with a higher level of nutritional knowledge feed their children more vegetable, fruit, legumes, and less sugared drinks. They also knew to avoid giving food that contained artificial flavouring and believes in the effects of nutrition to health as compared to mothers who had a lower level of nutritional knowledge. These mothers affect children's eating habits (Yabancı, Kısaç, \& Karakuş, 2014). Another factor that contributed to parents going out to fast food restaurants such as Mc Donalds and KFC is due to these settings offering playground facilities for their children that might contribute more to children's request of fast food. Moreover, working parents tend to eat out more due to having less time to cook at home (Abdullah, Mokhtar, Bakar, \& AlKubaisy, 2015).

The home environment has the potential to affect the overweight and obese children's energy balance and diet composition since parents act as a role model for their children and may influence the family environment by exposing family members to certain foods, by actively encouraging the family members to eat certain foods, or by passively allowing certain foods in the regular diets (Golan \& Crow, 2004). Overcoming this problem by following mothers to the wet market, the obese school children can develop their confidence level when they repeatedly practice the knowledge and skills that they attained from mothers while buying healthy ingredients (Sharif, Nor, Zahari, \& Muhammad, 2015).

\subsection{Knowledge on vegetables and fruits}

The result for good knowledge on vegetables shows an increase among the overweight and obese school children where they have better knowledge on vegetables after the intervention programme. The number of respondents with poor knowledge on vegetables decreased after the post-intervention. The same can be said for the results of good knowledge on fruits, which saw an increase after the intervention programme and poor knowledge on fruits decreasing after the intervention programme. The result indicates that the NEP has a significant increase to the knowledge of vegetables and fruits among overweight and obese children.

Overall, these results indicate that the NEP has significant influence before and after the nutritional educational on dietary pattern, healthy behaviour, attitude, environment, and knowledge among overweight and obese school children except environment. These proved that effective intervention should be focused on the dietary factor because inappropriate dietary habits lead to overweightness and obesity among school children (Baskova, Baska, \& Banovcinova, 2014). These findings were supported by a systematic review of 55 previous studies which mostly targeted children aged 6-12 years old. These included 37 studies of 27,946 children and demonstrated that the programs were effective in providing awareness towards the prevention of obesity among children (Waters et al., 2013). 


\subsection{Conclusion}

The research conducted aims to produce the ranking characteristics of housing qualities through its two objectives to be achieved which are finding out the characteristics quality of houses and ranking the importance of the characteristics quality. The overall evaluation by the researcher found out that the first and second objectives of the research have been achieved primarily through the methodology of literature review, Delphi Method, and Analytical Hierarchy Process. The research conducted was based on a small number of respondent thus enabling this research to be a pilot study for upcoming research to be undertaken.

\section{Acknowledgement}

The researcher acknowledges the other authors in this paper for giving tremendous support in completing this paper. Many thanks also to my dearest wife and daughter for your understanding. The researcher would also like to thank MyBrain15-KPT in giving the financial support in completing this paper.

\section{References}

Abdullah, L., Jaafar, S., \& Taib, I. (2013). Ranking of Human Capital Indicators Using Analytic Hierarchy Process. Procedia - Social and Behavioural Sciences, 107(2007), 22-28. http://doi.org/10.1016/j.sbspro.2013.12.394

Basten, C., \& Koch, C. (2015). The causal effect of house prices on mortgage demand and mortgage supply: Evidence from Switzerland R. Journal of Housing Economics, 30, 1-22. http://doi.org/10.1016/j.jhe.2015.07.001

Dinarvandi, M., Jafari, H., Mohamadi, M., \& Hosseini, A. (2014). Improving the Quality of Service to the Urban Environment for Sustainable Development. Procedia - Social and Behavioural Sciences, 120, 487-495. http://doi.org/10.1016/j.sbspro.2014.02.128

Goepel, A. K. D. (2010). BPMSG AHP Excel Template with multiple Inputs, 1-6.

Hartley, D. (2014). The effect of foreclosures on nearby housing prices: Supply or dis-amenity? Regional Science and Urban Economics, 49, 108-117. http://doi.org/10.1016/j.regsciurbeco.2014.09.001

Karim, H. A. (2012). Low-Cost Housing Environment: Compromising Quality of Life? Procedia - Social and Behavioural Sciences, 35(December 2011), 44-53. http://doi.org/10.1016/j.sbspro.2012.02.061

Masri, M. H. b M. @, Nawawi, A. H. b, \& Sipan, I. b. (2016). Review of Building, Locational, Neighbourhood Qualities Affecting House Prices in Malaysia. Procedia - Social and Behavioural Sciences, 234, 452-460. http://doi.org/10.1016/j.sbspro.2016.10.263

Mulliner, E., Smallbone, K., \& Maliene, V. (2013). An assessment of sustainable housing affordability using a multiple criteria decision-making method. Omega, 41(2), 270-279. http://doi.org/10.1016/j.omega.2012.05.002

Omar, D., Omar, K. A., Othman, S., \& Yusoff, Z. M. (2016). Youth Participation in Urban Neighbourhood Community. Procedia - Social and Behavioural Sciences, 234, 309-316. http://doi.org/10.1016/j.sbspro.2016.10.247

Panduro, T. E., \& Veie, K. L. (2013). Classification and valuation of urban green spaces-A hedonic house price 
valuation. Landscape and Urban Planning, 120,119-128. http://doi.org/10.1016/j.landurbplan.2013.08.009

Quyên, Đ. T. N. (2014). Developing University Governance Indicators and their Weighting System Using a Modified Delphi Method. Procedia - Social and Behavioural Sciences, 141, 828-833. http://doi.org/10.1016/j.sbspro.2014.05.144

Radeljak Kaufmann, P. (2016). Integrating factor analysis and the Delphi method in scenario development: A case study of Dalmatia, Croatia. Applied Geography, 71, 56-68. http://doi.org/10.1016/j.apgeog.2016.04.007

Rahadi, R. A., Wiryono, S. K., Koesrindartoto, D. P., \& Syamwil, I. B. (2013). Attributes Influencing Housing Product Value and Price in Jakarta Metropolitan Region. Procedia - Social and Behavioural Sciences, 101, 368-378. http://doi.org/10.1016/j.sbspro.2013.07.211

Safian, E., \& Nawawi, A. H. (2013). Characteristics of Purpose-built Office. Procedia - Social and Behavioural Sciences, 101, 575-584. http://doi.org/10.1016/j.sbspro.2013.07.230

Safian, E., Nawawi, A. H., \& Sipan, I. (2014). Building and Locational Characteristic's Quality of Purpose-Built Office and their Relationship with Rentals. MPRA, 64908(61160).

Saleh, A. F. A., Hwa, T. K., \& Majid, R. (2016). Housing Mismatch Model in Suburban Areas. Procedia - Social and Behavioural Sciences, 234, 442-451. http://doi.org/10.1016/j.sbspro.2016.10.262 